\title{
Research on Application of New Mode of Teaching Integration of EGP and ESP in College English Teaching
}

\author{
Zhihui Sun \\ School of Foreign Languages \\ Jingchu University of Technology \\ Jingmen, Hubei, China 448000
}

\begin{abstract}
Along with the increase in international cooperation projects, more and more talents with professional English application ability are needed in the employment market. In order to meet the needs of social development for compound talents, college English teaching must try to change the traditional and simple language teaching mode, strengthen the professional English teaching in combination with characteristics of the specialty studied by the students, to achieve the EGP plus ESP teaching mode, and continuously explore and improve teaching method, thus to build the college English teaching mode which meets China's actual situation.
\end{abstract}

Keywords-EGP; ESP; College English; integration mode

\section{INTRODUCTION}

Currently, there are two important branches of English teaching in colleges and universities. One is English for General Purpose, hereinafter referred to as EGP. In terms of teaching contents, EGP requires students to understand and master the basic knowledge of English language, and focus on the basic practice of English listening, speaking, reading, writing and translating, with the emphasis on language ability training. As for English education situation in China, the English teaching in primary school to high school belong to the teaching category of EGP. The second is English for Specific Purpose, hereinafter referred to as ESP. It refers to the applied English courses related to specific profession and subject. It mainly teaches the professional knowledge, and helps the learning object to realize the skill and professional knowledge of English. ESP is different from English for General Purpose, and is different from professional bilingual classes. Generally, it can be divided into scientific English, business English and social English.

\section{RELATIONSHIP BETWEEN EGP AND ESP}

From the point of teaching, because differences exist in the specific requirements applicable to both of them and the thinking mode of practitioners, and EGP and ESP have their own characteristics in terms of vocabulary, syntax, pragmatics and rhetoric, so the two have obvious differences. According

This paper is one of the research results of the sub-topic of key subject of Chinese Education Society's "Twelfth Five-year" plan of "Experiment and Research of College English Classroom Education Optimization under the Era of Big Data" Project number: 01020433 - HB1603. to the specific professional field, ESP can generate different effects in vocabulary characteristics, grammatical structure and chapter framework as well as means of expression. For example, the word "current", it is often used as an adjective meaning "now, recently", but in scientific English, it can also represent "electricity". "Bar" usually refers to the pub, but in legal English, it refers to the court, the judgment seat. Another example, the word "tie" is usually translated as "necktie" or "bow tie", but in the specialized English of rail transit, it is translated as "sleepers".

From the point of teaching purpose and teaching content, EGP mainly takes the common phenomenon of English language as the teaching content, to help the learners to learn and master universal characters of English language, thus improve the students' basic language skills. ESP course learning is related to the specific professional and career, with the focus on analysis and discussion of the particularity of various functions and styles of English, to serve for the actual application of particular profession.

Analyzing from the public perspective, specialized English takes the fundamental English vocabulary, sentence structure, grammar and tense as the premise and bedding. Obviously, EGP provides solid adaptive foundation for ESP learning mode, and ESP can successfully integrate the public cognition and professional skills, to expand students' knowledge indepth, at the same time, the knowledge of EGP is consolidated. As a result, the two language teaching branches of EGP and ESP supplements each other and is closely interrelated.

\section{CURRENT Situation OF DOMESTIC AND Foreign EsP TEACHING}

At present, the English teaching subject in most of colleges and universities is still the EGP courses. The traditional EGP teaching mode is adopted, focusing on the basic language skill training of listening, speaking, reading, writing and translating, so as to meet the need of students to take exams for certificates and English level, but it can't meet the needs of students' professional development. However, ESP courses are in the edge position in teaching within colleges, and there is no specific ESP teaching and research institutions, resulting in that the EGP and ESP teachers cannot communicate in a 
timely manner. In terms of teaching mode, the ESP teaching is mainly the word-for-word translation targeting at professional terminology and professional knowledge, and it is not accurate enough in terms of the explanation of grammar, sentence structure and rhetoric. In addition, some of the ESP teaching contents are boring and enigmatic, only the analysis of article structure and sentence patterns can be made for teaching activities. Students are expected to understand the systematic language knowledge gradually by virtue of the fragmentary grammar and vocabulary, resulting in their operating ability of the atmosphere involving emotion and context nearly to be zero, and students have little chance to use English. In the absence of practical teaching, students' interest in English learning is greatly reduced, resulting in their negative psychology of English learning. It can be seen that obvious disadvantages exist in ESP teaching in the majority of the colleges in China in terms of teaching materials, teaching mode and teachers. However, in the United States and England or the countries and regions with the background of English, such as Singapore, Romania, and India and other countries, and even Hong Kong, ESP teaching is the mainstream of college English teaching and has formed a relatively complete teaching system, while EGP course is only used for students with poor English foundation. So in these countries and regions, English has become the most basic technical language and working language.

\section{NECESSITY OF IMPLEMENTING EGP + ESP TEACHING MODE}

With the improvement of social requirements for English practice, the demand for "language + professional" talents by various industries is increasing. College English teaching cannot only focus on English language teaching, but shall pay attention to the connection of English and profession, to practice what they have learned. As a branch of English teaching, ESP teaching have more obvious target of teaching, which helps the cultivating of compound talents with both professional knowledge and foreign language skills a lot. It can be said that EGP provides language foundation for ESP, and ESP is the sublimation of EGP and professional knowledge. Only combine both of them very well, can the smooth transition from fundamental English to professional English be achieved, and transfer English application abilities into professional ability effectively, to better improve students' English level and quality.

\section{RESEARCH ON TEACHING Mode COMBINING EGP AND ESP}

\section{A. Conception of Curriculum Setting}

Cai Jigang [6] pointed out that: "we need to stick to the precedence relationship between fundamental English teaching and the teaching of English for special purposes. We shall be practical and realistic in terms of curriculum setting. For students without solid foundation, they shall mainly study fundamental English, and for students with good foundation, they should not do the endless practice on the basic abilities such as listening and speaking, but we shall make them start to learn the English for special purpose as soon as possible." It can be seen from the teaching research results of the majority of scholars that college English teaching needs two steps. Language foundation of EGP shall be laid first of all, to grasp the basic skills of listening, speaking, reading, writing and translating. And then study in combination with ESP courses, thus the cultivation target of professional English learning can be realized better, and cultivate the talents needed by the employers. Specific courses are suggested to be set as below: strengthen students' EGP learning in the freshman year and the first half of sophomore year, to improve students' basic skills of listening, speaking, reading and writing. From the second semester of sophomore year, set up the ESP and EGP courses simultaneously, add the scientific paper writing, international conference English and ESP optional courses starting from the third academic year, students can select relevant courses according to their interests and the specialty characteristics. For example, various kinds of vocational English, such as business oral English, hotel English, news English, legal English, secretarial English, art design English, etc. We shall strengthen students' understanding of English learning purpose in the teaching process, to enhance their confidence to be compound talents.

\section{B. Select or Compile Teaching Materials in Accordance with the Characteristics of Students and Specialty Characteristics}

Prior to selecting teaching materials, English teachers and students of various majors shall be interviewed and surveyed, and the use condition and effects of various specialties' English teaching material published in recent years shall be learned about, to ensure that the selected teaching materials are targeted, useful and credible. So the following factors shall be considered for selection of ESP teaching materials: select the teaching materials with moderate difficulty and strong practicality according to the characteristics of students' English learning; select the targeted and purposeful teaching materials according to the characteristics of various specialties; if there is no suitable professional English teaching materials, the experienced professional English teachers and EGP teachers of various colleges shall be encouraged to discuss with industry departments and industry experts relevant to the major in depth, to compile teaching material and supplementary teaching material jointly after integrating the overall situation and in accordance with cultivation goal of this specialty and students' actual level as well as weekly hours, and improve them in practice. Cai Jigang [6] pointed out that the focus of English teaching materials for special purposes shall be carried out around training students' language ability of specific subject, but not on the teaching of professional discipline's contents and knowledge. Therefore, the common vocabulary, syntactic structure and discourse function of the learners' discipline and major shall be compiled in the English teaching materials. The selected theme and contents as well as the purpose of teaching task setting shall aim at the language ability training required by the specialty. At the same time, the teaching contents that can stimulate students' participation and research interests shall be designed in combination with the characteristics of bilingual courses. 


\section{Improve Teaching Methods, and Pay Attention to the Mutual Penetration of Teaching Key Points of EGP and ESP}

Change the traditional cramming teaching method with student-centered method. While training students' ability of listening, speaking, reading, writing and translating, apply various teaching methods of EGP teaching flexibly into the ESP teaching, and the ESP learning plan can be infiltrated into EGP learning step by step. For example, teachers can create a professional learning English column, or ask students to translate some brief instructions and product introduction, or guide students to compile English dialogues that are associated with the specialty, organizes student to communicate and discuss the theoretical knowledge related to the specialty in English, to share the learning experience. In this process, teachers shall be able to find the students' pragmatic errors, and help students to correct problems in time, to improve their pragmatic competence.

Teachers can also create situation or lead students to the training base to carry out teaching in real situation by virtue of modern teaching methods, through methods such as task drive and communicative approach, according to the professional work process and the typical professional project, and choose appropriate teaching methods according to different situation. When students have entered into the unique scene, with the context atmosphere, then it is not just stay on the surface understanding of the teaching material content, but has strengthened the expression skills of professional English and fundamental English, achieving the efficient bridging effect of text and context. Students' adaptability is promoted, and through the preparing work before participation and the learning process, students' fear and negative mentality toward professional English is eliminated, at the same time, it is beneficial to help students solve the difficulties in English that may encounter in the future work. Effective foreign language learning properties indicate that the acquisition of language skills is not from education teaching, but from experience. Therefore, teachers need to make the language learning process possess the characteristics of experience and simulated experience through creating English environment. Through such kind of situational blended teaching activities, students' interest in learning can be greatly stimulated, and deepen the professional English language in students' mind through perception, understanding and practice.

In addition, English teachers should pay attention to the input of English cultural background knowledge, and cultivate students' cross-cultural communication ability consciously, strengthen practical writing skills of students from all specialties at the same time, including English business correspondence, job application in English and English academic exchange reports, etc. Supplement a variety of English newspapers and magazines, radio and television programs, guide students to make full use of network media resources or MOOC, micro classes and other forms of learning, to further arouse students' interest in learning English, enabling students to learn more knowledge of English.

\section{Reform Evaluation Model}

The teaching evaluation model with traditional final exam scores or English level test results as standard is no longer able to adapt to the requirements of current teaching mode and the applied talents cultivation. Therefore, it is necessary to establish the diversified teaching evaluation model, combine the process evaluation and summative evaluation as well as inclass and after-class evaluation, and involve every phase of the students in the whole process of English learning into the assessment, such as preview before class, classroom activity performance, after-class exercises as well as learning evaluation of various links of the practice activities. Focus on the evaluation of students' practical application ability of English, and the ability to deal with business related to future career using English. Evaluation subject can also adopt the diversified methods of teacher evaluation, classmate evaluation, self-evaluation and employer evaluation, to achieve the ultimate goal of promoting students' learning and teachers' improving of teaching.

\section{E. Strengthen the Construction of Teaching Staff}

The core of teaching reform lies in the construction of teaching staff. At present, ESP teaching level in domestic colleges and universities is not high. The teachers who are engaged in professional English teaching should not only have solid basic skills in English, but also shall have the professional knowledge taught by them, and are competent for teaching by virtue of a variety of teaching methods. As for the teachers only proficient in public English but not good at professional English, or the teachers who only understand professional knowledge but with weak foundation of English, the school shall set up ESP teaching and research institution, with the teaching team being made up of both EGP teachers and ESP teachers, to conduct business exchanges and cooperation as well as mutual learning in terms of curriculum setting, teaching material selection and course content cohesion. English teachers can also be sent to relevant departments or enterprises to exercise, so that they can learn about the knowledge and skills to be mastered by students specialized in this major while learning about relevant professional knowledge, which is conducive to integrate relevant professional knowledge and skills into fundamental English teaching process. Or invite the experts of English teaching in relevant specialties to offer lectures on special topics and teaching guidance. School can also encourage English teachers to study for the degree of other specialties according to their own interest or provide them with opportunity to study further; or encourage the bilingual teachers of other specialties to study for a degree in English major or to study further in English. Teachers should also be aware that they need continuous learning and development, to change knowledge structure and teaching ideas, enabling knowledge and ideas to keep pace with the times and create an excellent English teaching team meeting the English teaching model combining EGP and ESP.

\section{CONCLUSION}

In conclusion, building English teaching system by virtue of the model combining EGP and ESP fit the demand of talent 
construction by social development. The cultivation goal of compound talents of colleges can only be achieved by combining EGP basic learning and ESP practice application and continuous exploration, reform and innovation. Follow the college professional English teaching road that meets China's actual situation, to cultivate international professionals with higher comprehensive qualities for China.

\section{REFERENCES}

[1] Hou Jun, Chen Fang. Research on English Teaching Model Combining EGP and ESP in Higher Vocational Colleges [J]. Journal of Liuzhou Vocational and Technical College, 2012,12(3).

[2] Zhao Kui. Research on Application of EGP and ESP Teaching Integration New Model in English Teaching in Higher Vocational Colleges [J]. Education for Chinese After-School, 2015(33).

[3] Yang Xiaoli. English Teaching Model Combining EGP and ESP in Higher Vocational Colleges [J]. Journal of Yangtze University, 2012,35(3).

[4] Lei Wenhui. Research on Deep Integrated Teaching Mode of Fundamental English and Industrial English under the Background of Working-Learning Combination [J]. English Square, 2015(11).

[5] Du Lihua, Qi Xiaoqin. College English EGP and ESP Teaching Mode Combination in Science and Technology College [J]. Campus English, 2015(11).

[6] Cai Jigang. Development Direction of ESP and Chinese College English Teaching [J]. Foreign Language World, 2004, (2) : 22-28. 